\title{
The influence of academic supervision of school heads and work environment on teacher job satisfaction
}

\author{
Winaliyah Winaliyah ${ }^{1}$, Edi Harapan ${ }^{2}$, Nila Kesumawati ${ }^{3}$ \\ ${ }^{1}$ Sekolah Dasar Negeri 4 Betung \\ ${ }^{2}$ Universitas PGRI Palembang
}

\begin{tabular}{|c|c|}
\hline Article Info & ABSTRACT \\
\hline Article history: & \multirow{6}{*}{$\begin{array}{l}\text { This study aims to: } 1 \text {. determine the effect of principal academic supervision } \\
\text { on teacher job satisfaction; } 2 \text {. knowing the work environment on teacher job } \\
\text { satisfaction; } 3 \text {. to know the effect of principal's academic supervision and work } \\
\text { environment on teacher job satisfaction. The research method used is a } \\
\text { quantitative method. The results of this study indicate that: } 1 \text {. There is an } \\
\text { influence between the principal's academic supervision on teacher job } \\
\text { satisfaction; } 2 \text {. There is an influence between the work environment on teacher } \\
\text { job satisfaction; } 3 \text {. There is an effect of principal academic supervision and } \\
\text { work environment on teacher job satisfaction. }\end{array}$} \\
\hline Received Jul $15^{\text {th }}, 2021$ & \\
\hline Revised Aug $6^{\text {th }}, 2021$ & \\
\hline Accepted Aug $30^{\text {th }}, 2021$ & \\
\hline Keyword: & \\
\hline pervision & \\
\hline
\end{tabular}

work environment

Teacher job satisfaction

(C) 2021 The Authors. Published by IICET.

C) 2021 The Authors. Published by IICET.
This is an open access article under the CC BY-NC-SA license

(https://creativecommons.org/licenses/by-nc-sa/4.0

\section{Corresponding Author:}

Winaliyah Winaliyah

Sekolah Dasar Negeri 4 Betung

Email: winaliyah.sdn4btg@gmail.com

\section{Introduction}

The teacher is a very dominant and most important factor in formal education in general. Teachers are educators and teachers of role models and even self-identification figures. Therefore, teachers should have adequate behavior to be able to develop themselves completely [1].

Teachers play an important role in the educational process, therefore the needs of teachers need attention. Teachers need to get guidance and facilities at work so that teacher needs are met. If the teacher's needs are met, the teacher will feel satisfied at work. Job satisfaction will affect teacher productivity and performance, and both directly and indirectly have an impact on the quality of learning.

In line with the results of [2] which concluded that job satisfaction has a positive effect on teacher performance. It can be interpreted that the existence of good principal leadership and optimal teacher empowerment will strengthen the effect of job satisfaction on teacher performance. For this reason, the principal in increasing teacher job satisfaction can be done through: 1). Creating an atmosphere that can support increased teacher satisfaction, for example by providing learning facilities and equipment; 2). Creating a harmonious relationship between teachers through various informal activities such as holding field trips, sports competitions and others.

Good supervision will be able to improve the performance of subordinates and in the end employee satisfaction with their work will increase. Supervision is often called supervision in the context of schooling. 
Supervision can be carried out by the principal or by supervisors who carry out their main duties and functions to guide and supervise the education unit. This is in line with the results of research conducted [3], there is a significant positive relationship between principal supervision and teacher job satisfaction.

Based on the results of this study, it means that the supervision carried out by the principal can increase teacher satisfaction at work. If the supervision carried out by the principal or supervisor can increase teacher professionalism, teacher job satisfaction can increase.

Achievement of optimal teacher job satisfaction is influenced by internal and external factors. Internal factors, namely the drive to work, responsibility for the task, interest in the task. Meanwhile, external factors are respect for assignments, opportunities for development, attention from school principals, interpersonal relationships among teachers, training, guided discussion groups, and library services [4].

The success of education in schools is largely determined by the success of the principal in supervising the teaching staff at school. The principal is one component of education that is very influential in increasing teacher job satisfaction. The principal is responsible for the provision of education, school administration, manpower development, and maintenance of facilities and infrastructure.

Apart from the importance of the problem of academic supervision, there are still things that will affect teacher job satisfaction, namely the work environment. Teachers will be able to carry out their duties properly if supported by a good work environment too. A healthy, comfortable, and conducive work environment will be able to increase teacher productivity so that it will increase teacher job satisfaction. But in reality, not all schools have a conducive environment. Some elementary schools in the Betung sub-district are located right on the edge of the main road, often side by side with busy centers such as markets. This is of course very influential on the teaching and learning process itself.

The work environment is everything that is around the workers and which can affect them in carrying out their assigned tasks, for example cleaning, music, lighting and others [5].

There are many factors that affect the level of job satisfaction of a worker in carrying out activities that have been charged by the school. Principal's academic supervision factor needs to be considered in an effort to create job satisfaction because it is related to the perception of the worker concerned. In addition to the academic supervision of the principal, work environment factors also influence the level of job satisfaction. The conducive work environment felt by workers will create job satisfaction for them in their activities.

Research conducted [6] shows that: 1) Academic Supervision has an effect on the performance of Mathematics teachers, 2) The Work Environment affects the performance of Mathematics Teachers, 3) Academic Supervision and Work Environment jointly affect the Performance of Economic Teachers.

Researchers made observations in several schools in SD Negeri in Betung District. From these observations, the researcher found that teachers do not have adequate work space. It is said to be inadequate because the teacher's office is not very large but must be divided into three rooms, namely the teacher's office, administration room, and the principal's room. Even though the teacher should have enough space to be able to work comfortably. If these environmental factors are not considered properly, it is feared that teacher performance will also not run as it should. The teacher will also feel lazy to come to the office, the teacher will not carry out his duties as a teacher to the fullest.

Based on the above problems, according to the author, "The Effect of Principal Academic Supervision and the Work Environment on Teacher Job Satisfaction at Public Elementary school all Betung District" is important to be studied.

The purpose of this study was to identify, describe, and analyze the effect of principal academic supervision and work environment on teacher job satisfaction at Public Elementary school all Betung District.

\section{Method}

The method in this research is a quantitative method. because the data obtained will be realized in the form of numbers and analyzed based on statistics. A quantitative approach is used to examine a particular population or sample by using a random sampling technique [7]. Collecting data using statistical analysis instruments, with the aim of testing the hypothesis set.

The population in this study were 192 Public Elementary school teachers in Betung District, with a sample of 116 people. Data collection techniques through questionnaires / questionnaires, observation and documentation. Before the questionnaire is distributed to respondents, it is tested for validity and reliability first. 
The analysis implementation stage includes: (1) descriptive analysis, (2) analysis requirements test: normality test, linearity test, and (3) multicollinearity test. The data analysis technique in this study used simple regression and multiple regression data analysis techniques with the help of the SPSS version 24 program.

\section{Results and Discussions}

\section{The Effect of Principal's Academic Supervision on Satisfaction Teacher Work}

Based on the results of hypothesis testing, the t-count value is 4,803 and the t-table value is 1,658 which means that $\mathrm{Ho}$ is rejected and $\mathrm{Ha}$ is accepted, which means that the principal's academic supervision (X1) has a significant effect on teacher job satisfaction (Y). The significant level of the Principal Academic Supervision variable (X1) is 0,000 smaller than the $\alpha$ value $(0,05)$, thus $\mathrm{H} 0$ is rejected and $\mathrm{Ha}$ is accepted, so it can be concluded that the Principal Academic Supervision variable (X1) has a significant effect on teacher job satisfaction (Y) in Public Elementary school in Betung District.

Academic supervision is assessing and fostering teachers in order to improve the quality of the learning process so that student learning outcomes are more optimal [8].Supervision carried out by the principal maximally and programmed as well as possible, will foster teacher job satisfaction in carrying out their duties. Supervision that has been carried out by the head of the school properly and continuously will affect teacher job satisfaction.

Based on the above understanding, the better the implementation of supervision by the principal, of course, can increase teacher job satisfaction in carrying out their daily duties. In other words, it can be said that if the principal can plan academic supervision well, carry out academic supervision well and can follow up on the results of supervision effectively, it will certainly encourage an increase in teacher job satisfaction in carrying out tasks at school.

This research is also supported by previous research conducted [9], the results of the study show that the supervision of the principal has a positive and significant effect on teacher job satisfaction. Academic supervision of principals to teachers has a positive and significant effect on teacher job satisfaction. This means that if supervision activities are carried out by the principal, it can increase teacher job satisfaction and vice versa. This is in accordance with the theory of "supervision is complex role in professional education. with an all-important mission of improving the learning experience for students, that role remains constant despite changes in schools [10]. In other words, supervision has a complex role in building education into a professional with a mission to improve the learning experience or learning quality for students, even though changes in schools occur because of the supervision process carried out. So, it can be concluded that the effect of principal supervision on teacher job satisfaction indicates that if the supervision of the principal is implemented it will make a real contribution to increasing teacher job satisfaction. Here there is a match between the results of the research and existing theories. In other words, the results of this study support existing theories.

\section{Effect of Work Environment on Teacher Job Satisfaction}

Based on the results of hypothesis testing, it was obtained that the t-count value was 5,002 and the t-table value was 1,658, which means that Ho was rejected and $\mathrm{Ha}$ was accepted, which means that the work environment (X2) has a significant effect on teacher job satisfaction (Y). The significant level of the Work Environment variable (X2) is 0,000 smaller than the $\alpha(0,05)$, thus $\mathrm{H} 0$ is rejected and Ha is accepted, so it can be concluded that the Work Environment Variable (X2) has a significant effect on teacher job satisfaction (Y) in Public Elementary school in Betung District.

Work environment is the entire work facilities and infrastructure around employees who are doing work that can affect the implementation of work including workplaces, facilities, cleanliness, lighting, tranquility, including work relations between the people in the place. So that employee morale will increase [11].Work environment factors have a big influence on the enthusiasm and enthusiasm of work, namely a clean work environment, good lighting but not dazzling, the exchange of good air that nourishes the body, guarantees for security that creates calm [12].

The results of this study are in accordance with the theory expressed by stating that the work environment is everything that is around workers and can influence them in carrying out their assigned tasks. The work environment is also useful in creating work passion so that job satisfaction increases [13].

The results of this study are also in accordance with previous research conducted [14]. In this study, the results obtained that the work environment has a significant effect on job satisfaction of teachers and employees. 
Based on the research results above, it can be concluded that the work environment affects teacher job satisfaction. If the working environment conditions are good and conducive, the teacher can produce good performance and increased productivity, so that job satisfaction will increase and vice versa.

\section{Effect of Principal Academic Supervision and Work Environment on Teacher Job Satisfaction}

Based on the results of multiple linear regression calculations, it is known that the constant is 35,590 , meaning that if the academic supervision of the principal and the work environment is zero, then the teacher's performance is 35,590. The regression coefficient of the principal's academic supervision variable is 0,040 , meaning that if the principal's academic supervision has increased by one unit, the teacher's performance will increase by 0,040 , assuming other independent variables are of fixed value. Because the regression coefficient is positive, it can be said that the principal's academic supervision (X1) has a positive effect on teacher job satisfaction (Y). The regression coefficient for the work environment variable is 0,530 , meaning that if the work environment has increased by one unit, the teacher's job satisfaction will increase by 0,530 units, assuming the other independent variables are of fixed value. This means that Principal Academic Supervision and Work Environment always have a positive increase in teacher job satisfaction.

Based on this research, the role of academic supervision by the principal and the work environment is needed to increase teacher job satisfaction through coaching and guidance carried out by the principal. The satisfaction felt by the teacher because the principal can carry out supervision activities properly and a conducive work environment will increase his motivation in carrying out his duties, so that the teacher will work voluntarily. Teacher volunteerism on duty will increase the productivity of their performance. Increased teacher job satisfaction will be easier to achieve the goals previously set. Conversely, if the teacher is not satisfied with the supervision carried out by the principal, then their motivation will decrease and result in their low productivity, and will affect teacher job satisfaction.

The results of this study are also supported by previous research conducted [9], the results of the study show that the supervision of the principal and the work motivation of teachers together have a positive and significant effect on teacher job satisfaction at SMK Adb Invest in Surabaya.

This research is also supported by research conducted [6], where the results show that: (1) Academic Supervision has an effect on Mathematics teacher performance, (2) Work Environment affects Mathematics teacher performance, (3) Academic Supervision and Work Environment jointly affect the performance of economic teachers.

This study is also in line with [15] research results, the results show that: (1) There is a significant effect of motivation on teacher job satisfaction at SMK PGRI Sukoharjo Academic Year 2012/2013, (2) There is a significant effect of the work environment on satisfaction. teacher work at SMK PGRI Sukoharjo 2012/2013 Academic Year, and (3) There is a significant influence on motivation and work environment together on teacher job satisfaction at SMK PGRI Sukoharjo Academic Year 2012/2013.

Satisfaction is an important key for every individual in carrying out their activities, including teachers in carrying out their routine at school in the form of teacher job satisfaction. Teacher job satisfaction is a reflection of a teacher's attitude and feelings towards his job in teaching and learning activities at school. The attitudes and behavior of teachers who are satisfied with their work are characterized by a sense of pride in their work, enjoy their work, are passionate about work, carry out their work with full responsibility [16]. Job satisfaction can be understood through three aspects. First, job satisfaction is a form of worker response to work environmental conditions. Second, job satisfaction is often determined by job results or performance. Third, job satisfaction is related to other attitudes and is owned by every worker [17].

\section{Conclusion}

Based on data analysis and hypothesis testing, the following conclusions can be drawn: 1) There is an influence between the principal's academic supervision on teacher job satisfaction at Public Elementary school all Betung District. 2) There is an influence between the work environment on teacher job satisfaction at Public Elementary school all Betung District. 3) There is an effect of the principal's academic supervision and work environment on teacher job satisfaction in Public Elementary school all Betung District.

\section{References}

Wijaya, C., and Rusyan, T. 1994. Teacher Ability in Teaching and Learning Process. Bandung: PT. Rosdakarya youth. 
Pujiyanti \& Handayani. 2011. The Effect of Job Satisfaction on Teacher Performance with Principal Leadership and Teacher Empowerment as Moderation Variables in SD Negeri UPTD Dikpora, Sayung Demak District.

Manarus R. 1996. The relationship between principal supervision and job satisfaction of elementary school teachers. Journal of Educational Sciences, 3 (3): 189-199.

Mulyasa. 2007. Becoming a Professional Teacher creates Creative and Fun Learning. Bandung: Rosdakarya.

Sunyoto, D. 2012. Human Resource Management. Jakarta: PT Buku Seru.

Suharto. The Effect of Principal Academic Supervision and the Work Environment on the Performance of Vocational High School Mathematics Teachers in Bengkulu City. Raflesia Mathematics Education Journal. 3 (2): $2548-443$.

Sugiyono. 2013. Quantitative Research Methods, Qualitative and R \& D. Bandung: CV. Alfabeta.

Sudjana, Nana. 2011. Assessment of Teaching and Learning Outcomes and Processes. Bandung: Rosda Karya.

Rifaldi. 2014. The Effect of Principal Supervision and Teacher Work Motivation Results on Teacher Job Satisfaction at ADB Invest Vocational Schools in Surabaya City. Thesis. Faculty of Education: Surabaya State University: Surabaya.

Willes, J. and Bondi, J. 1986. Supervission a Guidden to Practice. Secon Edittion. Columbus: Charles E. Merril Publishing Company.

Sutrisno, Edi. 2009. Human Resource Management First Edition. Jakarta: Kencana Prenada Media Group.

Melanie, Ella. 2014. "The Influence of Employee Placement, Work Environment and Work Motivation on Employee Performance in the Center for Implementation of Jalan Nasional II West Sumatra". Thesis. Padang: Graduate Program in Management from Putera Indonesia University "YPTK" Padang.

Nitisemito. 2001. Personnel Management, Second Edition. Ghalia Indonesia.

Firmansyah, Farid. 2008. The Effect of Work Environment, Compensation, and Leadership on Job Satisfaction of Teachers and Employees at SMA Wachid Hasyim Surabaya. Tadris Journal. 3 (1): 93-105.

Supriyanto. 2013. The Effect of Motivation and Work Environment on Teacher Job Satisfaction at SMK PGRI Sukoharjo Academic Year 2012/2013. Thesis. Semarang State University Postgraduate Program: Semarang.

Efrilya, H. 2013. The Effect of Job Satisfaction on Teacher Performance in SMA Negeri 2 Kampar. Journal of History Study Program. 4 (1): 2355-3774.

Engko, C. 2008. The Effect of Job Satisfaction on Individual Performance with Self Esteem and Self Efficacy as Intervening Variables. Journal of Business and Accounting, Faculty of Economics, Pattimura University. 10 (1): $1-12$. 